\title{
WHY CASH-BASED BUDGETING STILL PREVAILS IN AN ERA OF ACCRUAL-BASED REPORTING IN THE PUBLIC SECTOR
}

\author{
Christoph Reichard \\ University of Potsdam \\ and \\ Jan van Helden \\ University of Groningen
}

\begin{abstract}
$\mathrm{T}$

his paper discusses the phenomenon that governments in many Western countries have transferred their cash-based systems into accrual-based systems for reporting purposes during the last decades, while still retaining cashbased budgeting systems. The main question we want to answer is whether there are more substantial reasons why governments prefer cash above accruals for budgeting. Our paper is the result of a comprehensive literature review. At first glance, combining accruals for both budgeting and reporting seems to be preferable above combining cash for budgeting and accruals for reporting: there is consistency between the budgeting and reporting logic, and accrual information is richer than cash information. However, we are in favour of a more nuanced perspective. The combination of cash for budgeting and accruals for reporting can be defended through the lens of a fundamental budgeting logic that identifies all expenditures and revenues expected for the budget year and sees the comparison between cash-based appropriations and actual cash outflows as an easy and straightforward control mode. Moreover, this combination aligns with the dominance of budgeting over reporting and the limited accounting expertise of many accounting information users (for example, public sector managers and especially politicians). We argue that the ultimate transfer from cash to accruals in budgeting needs to be based on a solid assessment of its added value to these users, and not due to pressures of accounting experts.
\end{abstract}




\section{INTRODUCTION}

In line with broader public management reforms, governments of various countries around the world (particularly in Europe) have, over the last few decades, changed their accounting systems from a traditional cash mode to accrual-based systems. These reforms were often in accordance with the harmonisation of private sector accounting standards (for example, towards International Financial Reporting Standards - IFRS) and gained support from the emergence of International Public Sector Accounting Standards (IPSAS). As a consequence, a number of countries now use accrual systems and generate the usual financial reporting documents (such as income statements and balance sheets) as a basis for reporting. However, when taking a closer look at these reforms, the observer will discover that many of these countries have not changed their budgeting systems (and still maintain such systems on the basis of cash). Such a cash budgeting and accrual reporting (CB\&AR) mode appears somewhat contradictory and inconsistent from a financial management perspective. Our aim, and the corresponding research question therefore, is to investigate the rationale behind the lack of alignment of the two systems. What were the reasons and arguments of the respective governments to follow this mode? Is it only a matter of time before countries will move to accrual budgeting, or are more fundamental reasons at stake? Moreover, we want to discuss and critically assess the various arguments in favour of and against the cash budgeting mode (and correspondingly in favour of and against the accrual budgeting mode).

This paper is predominantly based on a review of the public sector management literature with cash-based and accrual-based budgeting as main search terms. Given that this theme has gained attention in the academic and practice-oriented literature quite recently, our search for publications was mainly focused on the last fifteen years. Google Scholar was used for a first identification of relevant academic papers. After reading the selected papers and assessing their potential appropriateness for our research project, complementary papers were identified through the so-called snowball method (identification of additional papers based on the references of the originally selected papers). In order to acknowledge that sources other than academic journals might be important outlets for publications on the theme at hand, we included edited books, papers from practice-oriented journals and reports published by consultancy firms in our database of publications. All publications were read and critically assessed in the light of the above indicated research question. In addition, we contacted the authors of recently published studies on those countries that have adopted cash for budgeting and accruals for reporting, for clarification of, among other things, the possible reasons for adopting such a budgeting and reporting mode.

This paper is structured as follows: in the next section we present a general empirical picture of countries following various budgeting and reporting modes. Here we describe some particularities of six European countries (Belgium, Denmark, Greece, France, Portugal and Spain) using the CB\&AR mode. This is followed by an explanation of the differences between accrual and cash budgeting and an illustration of particular circumstances in public sector organisations (PSOs) which may lead to differences between the two budgeting modes. In the penultimate section 
Why Cash-Based Budgeting Still Prevails in an Era of Accrual Reporting in the Public Sector

we discuss and assess various arguments pro and contra cash/accrual budgeting which we found in our literature review. In the final section we discuss our findings and draw some conclusions.

\section{THE EMPIRICAL PICTURE: CASH BUDGETING IN AN ERA OF ACCRUAL ACCOUNTING}

This section reports the extent to which governments in various groups of countries have adopted accrual-based accounting for reporting, while continuing to use a cash-based budgeting system. The reviewed studies mainly differ regarding the specific group of countries they address: worldwide (PricewaterhouseCoopers, 2015), Organisation for Economic Co-operation and Development (OECD) countries (Moretti, 2016), or a group of fourteen European countries (Brusca et al., 2015a). In addition, an older OECD study is included (Blöndal, 2004), so that some developments can be tracked over time. Except for the study by Brusca et al. (2015a), which examines various governmental levels - central, intermediate and local - the other studies are all concerned with central government.

Combining either cash or accruals with budgeting and financial reporting gives rise to four possible combinations:

- Cash for budgeting and reporting (CB\&CR)

- Cash for budgeting and accruals for reporting (CB\&AR)

- Accruals for budgeting and cash for reporting (AB\&CR)

- Accruals for budgeting and reporting (AB\&AR)

However, because the third combination - accruals for budgeting and cash for reporting - never occurs, three combinations remain, and these combinations are shown in Table 1 for each of the above studies. When comparing the different modes, we should be aware that budgeting is a process with several stages, covering an ex-ante view (i.e. budget formulation and decision for the coming year) as well as an ex-post view (budgetary accounting for controlling budget execution during and after the respective budget year to identify differences between actual and planned appropriations). To some extent, financial accounting, which usually is ex-post-focused, can also have an ex-ante perspective, for instance, with regard to financial forecasting of future expenses or revenues.

The number of countries following the AB\&AR mode, at least at the central government level, varies between 18 and 36 per cent. In addition to Australia and New Zealand, and to a limited extent Canada, we find five countries using the AB\&AR mode in Europe: Austria, Finland, Sweden, Switzerland and the United Kingdom (UK). The lowest percentage of the AB\&AR mode (18 per cent) is noted in the worldwide study, while substantially higher percentages are recorded for OECD countries (32 per cent) and European countries (36 per cent). This suggests that accrual budgeting and reporting are far less adopted in poor than rich countries. In addition, the subsequent OECD studies indicate that accrual reporting has 
TABLE I: OVERVIEW OF STUDIES ONTHE APPLICATION OF CASH OR ACCRUALS FOR BUDGETING AND REPORTING IN GOVERNMENTS

\begin{tabular}{|c|c|c|c|c|c|}
\hline Study & $\begin{array}{c}\text { Observation } \\
\text { Period }\end{array}$ & $\begin{array}{l}\text { Focus and } \\
\text { Number of } \\
\text { Countries }\end{array}$ & $\begin{array}{c}\% \text { of } \\
\text { Countries } \\
\text { Applying } \\
\text { Cash for } \\
\text { Budgeting } \\
\text { and } \\
\text { Reporting }\end{array}$ & $\begin{array}{c}\% \text { of } \\
\text { Countries } \\
\text { Applying } \\
\text { Cash for } \\
\text { Budgeting } \\
\text { and Accruals } \\
\text { for Reporting }\end{array}$ & $\begin{array}{c}\% \text { of } \\
\text { Countries } \\
\text { Applying } \\
\text { Accruals for } \\
\text { Budgeting } \\
\text { and } \\
\text { Reporting }\end{array}$ \\
\hline $\begin{array}{l}\text { PWC } \\
(2015)\end{array}$ & $2014-2015$ & $\begin{array}{l}\text { I20 countries } \\
\text { worldwide (central } \\
\text { government) }\end{array}$ & $48 \%$ & $34 \%$ & $18 \%$ \\
\hline $\begin{array}{r}\text { Blöndal } \\
\text { (2004) }\end{array}$ & 2003 & $\begin{array}{l}29 \text { OECD } \\
\text { countries (central } \\
\text { government) }\end{array}$ & $69 \%$ & $10 \%$ & $21 \%$ \\
\hline $\begin{array}{l}\text { Moretti } \\
(2016)\end{array}$ & $2015-2016$ & $\begin{array}{l}34 \text { OECD } \\
\text { countries (central } \\
\text { government) }\end{array}$ & $18 \%$ & $50 \%$ & $32 \%$ \\
\hline \multirow[t]{2}{*}{$\begin{array}{l}\text { Brusca } \\
\text { et al. } \\
(2015 b)\end{array}$} & 2014 & $\begin{array}{l}\text { I4 European } \\
\text { countries (central } \\
\text { government) }\end{array}$ & $28 \%$ & $36 \%$ & $36 \%$ \\
\hline & & $\begin{array}{l}\text { I I European } \\
\text { countries (local } \\
\text { government)* }\end{array}$ & $10 \%$ & $45 \%$ & $45 \%$ \\
\hline
\end{tabular}

*The number of countries for which usable local government information is available in the book is eleven, because in three countries (Denmark, Italy and UK) there are no consistent and homogeneous regulations concerning the type of accounting or budgeting concept at local level. Additionally, we are deviating with regard to two countries (Austria and Germany) from the classification of Brusca et al. (20l5b). With reference to additional information, we have attributed these countries to the dominant category, i.e. the one to which the majority of local governments can be assigned (Austria to the CB\&CR mode and Germany to the AB\&AR mode).

Source: compiled by the authors.

increased substantially between 2003 and 2016. Table 1 further indicates that the number of countries in the CB\&AR mode is substantial, varying (in central government) between 10 per cent (worldwide) and 50 per cent (OECD countries in 2016). The Brusca et al. (2015b) comparative study also reveals that this combination has an important role in European local government (45 per cent of the countries). Taking a worldwide view, the findings indicate that the combination of cash budgeting and reporting $(C B \& C R)$ is still the most often used mode (48 per cent of countries), with poorer countries particularly availing of this mode of operation.

Subsequently, we will further focus our analysis on the Brusca et al. (2015b) study for two reasons. First, in contrast to the other research, this study covers both central and local government. Second, this study provides considerable background information relating to each of the countries (for which separate studies were conducted - see Brusca et al., 2015a). This provides us with deeper insights into the way cash or accruals, or combinations of both, are applied. As such, it can also help to identify possible reasons for particular preferences (a key focus of this 
Why Cash-Based Budgeting Still Prevails in an Era of Accrual Reporting in the Public Sector

paper). Our analysis is based on two sources: the already mentioned country studies in the Brusca et al. (2015a) book, and additional information provided by the authors of these studies upon our request. The latter information was aimed at clarifying certain specifics of the budgeting and reporting mode in each of the countries. Moreover, it allowed more informed insights relating to two issues: the reasons for adopting the CB\&AR mode, and the match or lack of match between the structure of the cash-based budget (in terms of items or articles) and the structure of the accrual-based income statement. ${ }^{2}$

Although the Brusca et al. (2015b) study distinguishes between three levels of government - central, intermediate and local - we confine ourselves to central and local government, acknowledging that intermediate governments are difficult to compare (for example, states in the federal system of Germany and provinces in the unitary system of Netherlands). In addition to pure cash- or accrual-based systems, the Brusca et al. (2015b) study identifies modified cash and modified accrual systems being used. A modified cash system is primarily a cash system which includes some accrual elements, often commitments at the year-end (which will lead to cash outflows in the first months of the next year). A modified accrual system is merely an accrual system, but it may ignore, for example, the depreciation of particular fixed assets (for example, heritage and defence) or certain liabilities, such as pension obligations (see, for definitions: International Federation of Accountants, 2000; PricewaterhouseCoopers, 2015, p. 11).

If we combine cash and modified cash in one category, and also combine accrual and modified accrual in another category, Table 2 shows which European countries apply the budgeting and reporting modes under investigation (CB\&CR, CB\&AR and $A B \& A R)$. This table reveals some consistency in these modes across governmental layers, that is, central and local government in the same country using parallel modes. This is the case in Belgium, Denmark, France, Portugal and Spain for the CB\&AR mode, as well as Finland, Sweden, Switzerland and the UK for the AB\&AR mode. The other five countries, Austria, Germany, Greece, Italy and the Netherlands, are using partly or fully diverging modes for central and local government.

Given the focus of our research (why countries combine cash for budgeting and accruals for reporting), the following six countries, which use this mode, are investigated further: Belgium, Denmark, Greece (only local government), France, Portugal and Spain. ${ }^{3}$ A further examination of these countries is possible because the Brusca et al. (2015a) book comprises country studies of all fourteen included countries. We will try to answer two questions:

- To what extent are the identified countries similar in public sector budgeting and reporting practices?

- What are the reasons standard setters and practitioners in these countries give for preferring a combination of cash-based budgeting and accrual-based reporting?

While each of the six identified countries combine cash-based budgeting and accrual-based reporting, there are also notable differences. First, in Belgium, Flemish local government combines cash and accrual budgeting (Christiaens and Neyt, 
TABLE 2: CASH OR ACCRUALS FOR BUDGETING AND REPORTING IN GOVERNMENTS OF SELECTED EUROPEAN COUNTRIES

\begin{tabular}{|c|c|c|c|c|}
\hline $\begin{array}{c}\text { Government } \\
\text { Level }\end{array}$ & $\begin{array}{c}\text { Countries } \\
\text { Applying Cash } \\
\text { for Budgeting } \\
\text { and Reporting }\end{array}$ & $\begin{array}{c}\text { Countries } \\
\text { Applying Cash } \\
\text { for Budgeting } \\
\text { and Accruals for } \\
\text { Reporting }\end{array}$ & $\begin{array}{l}\text { Countries } \\
\text { Applying } \\
\text { Accruals for } \\
\text { Budgeting and } \\
\text { Reporting }\end{array}$ & $\begin{array}{l}\text { Countries with } \\
\text { Heterogeneous } \\
\text { or Ambiguous } \\
\text { Accounting or } \\
\text { Budgeting Modes }\end{array}$ \\
\hline $\begin{array}{l}\text { Central } \\
\text { government }\end{array}$ & $\begin{array}{l}\text { Germany, } \\
\text { Greece, } \\
\text { Netherlands* }\end{array}$ & $\begin{array}{l}\text { Belgium, Denmark, } \\
\text { France, Portugal, } \\
\text { Spain }\end{array}$ & $\begin{array}{l}\text { Austria, Finland, } \\
\text { Sweden, } \\
\text { Switzerland, UK }\end{array}$ & Italy** \\
\hline $\begin{array}{l}\text { Local } \\
\text { government }\end{array}$ & Austria*** & $\begin{array}{l}\text { Belgium, France, } \\
\text { Greece, Portugal, } \\
\text { Spain }\end{array}$ & $\begin{array}{l}\text { Finland, Germany, } \\
\text { Netherlands, } \\
\text { Sweden, } \\
\text { Switzerland }\end{array}$ & $\begin{array}{l}\text { Italy,** } \\
\text { Denmark,**** } \\
\text { UK***** }\end{array}$ \\
\hline
\end{tabular}

* Central government agencies in the Netherlands mostly apply accrual budgeting and accounting.

* In Italy, for both central and local government, reporting also contains elements of accrual accounting; so, the country seems to use a hybrid system of both cash and accrual elements (source: Manes Rossi, 2015, as well as additional information provided by this author).

*** In Austria, the majority of municipalities are still applying cash for budgeting and reporting, but some of them have moved to the AB\&AR mode; in the next few years the rest of them will follow (source: Rauskala and Saliterer, 2015).

**** Danish local government uses also some cash elements in its reporting system and municipalities have the right to choose between cash and accrual modes for budgeting (source: Aggestam Pontoppidan, 2015, as well as additional information provided by this author).

****** There are no explicit legal prescriptions in the UK for a specific accounting and budgeting mode for local government.

Source: compiled by the authors.

2015), while governments in the other countries exclusively rely on cash or modified cash for their budgeting system. A recent study (Buylen and Christiaens, 2016) shows that cash-based issues (such as current expenditures by destination or capital expenditures by destination) are used to a larger extent than accrual elements (such as depreciation of assets) in Flemish local government. Second, in Denmark, municipalities have the option to choose between accrual and cash for budgeting (Aggestam Pontoppidan, 2015), while this is not the case in the other countries. Third, several countries seem to have what is referred to as 'integrated accounting systems', indicating that both cash information about budget appropriations and budget execution, as well as accrual information for the income statement and balance sheet, can be derived from the same system. This applies to Belgium for local government (Christiaens and Neyt, 2015), Spain (Brusca, Montesinos and Vela, 2015) and Portugal (Jorge, 2015). The provided information about the countries using the CB\&AR mode clearly indicates that there is in general no match between the structure of the cash-based budget report and the accrual-based income statement. While the cash-based budget is structured according to functions (or programmes), the accrual-based income statement is structured according to line items (for example, total salary costs and total depreciation costs). This implies that under such a mode accrual-based information is not appropriate for controlling and for giving account 
of the budget execution. ${ }^{4}$ Fourth, Greece seems to have adopted accrual elements very recently (Cohen, 2015), largely due to pressures related to the financial crisis, while other countries have longer histories of reforms in which accrual accounting is core. Finally, some countries are inspired by IPSAS in their reforms (Belgium, France, Spain, Portugal), while others deliberately stick to their own history of national standard setting (Denmark), or are faced with such major shortcomings in their current accounting systems that IPSAS may be a step too far (Greece).

The country studies do not extensively provide arguments for the preferred combination of cash budgeting and accrual reporting. Rather than being the result of explicit and extensive debates, the decision for the CB\&AR mode seems to be the outcome of implicit reasoning about the assumed information preferences of politicians and public sector managers. In this reasoning two arguments in favour of the CB\&AR mode dominate: the mindset of these users of public sector budgets is cash-oriented and they lack the expertise for using accrual-based information. In addition, some more specific arguments were provided: accrual-based budgeting could be more risky; it is convenient to have two types of accounting systems serving different purposes; and the use of accrual information is poor (for more arguments relating to the CB\&AR mode, see the later section which explores its pros and cons).

\section{WHICH CIRCUMSTANCES IN A PSO LEAD TO DIFFERENCES BETWEEN CASH BUDGETING AND ACCRUAL BUDGETING?}

For an appreciation of the competing arguments relating to cash-based budgeting and accrual-based budgeting, an exploration of the financial effects of their adoption by a public sector organisation (PSO) is important. First, a brief introduction of public sector budgeting is provided: according to Wildavsky (1984, p. 4), a budget is a monetary representation of the planned activities of a governmental organisation. In a more elaborate way, a budget can be defined as an overview of the activities, categorised according to functions, programmes and/or organisational units, of a governmental organisation over a certain future period, in the form of at least its financial aspects (both revenue and cost items), and often supplemented by other information about these activities, such as their goals or desirable impacts (see, for example, van Helden and Hodges, 2015, p. 111). Traditionally, budgeting has been the process through which governments decide how much to spend on which activity, limiting expenditures to the revenues available and preventing overspending. In a broader sense, budgeting has increasingly been expected to perform other roles and functions (for example, enforcing managerial responsibility, discharging a strengthened external accountability and supporting macroeconomic steering of the economy - see, for instance, Anessi Pessina et al., 2016, p. 492).

There are different variables which can be modified when composing a public budget: which aspects of government activities should the budget inform (for example, financial inputs, targets, outputs or outcomes)? How long is the planning period (one or more years)? What should the main criterion of structuring be (following the organisation or along programmes, products, etc.)? How detailed should the budget be (highly differentiated into thousands of items or more aggregated)? How 
flexible is the process of budget execution (binding detailed appropriations or offering options for carrying over, etc.)? How does the process of budget formulation proceed (bottom-up versus top-down)? And finally, what is the accounting basis of the financial information used in the budget (cash or accrual)? Budgeting reforms usually deal with one or several of these variables. In this paper, we are primarily concerned with the last issue: the use of cash- or accrual-based financial information within the budgeting process.

Having described some essentials and characteristics of public budgets, we now explore the circumstances in PSOs under which CB (cash budgeting) leads to either quite similar or to substantially diverging financial outcomes than $\mathrm{AB}$ (accrual budgeting). The core difference between cash and accrual accounting and budgeting is as follows (van Helden and Hodges, 2015, pp. 46-47): a cash-based system registers cash outflows (payments) and cash inflows (receipts) when they occur, while under an accrual-based system, revenues and costs are recognised when they are earned and incurred respectively, not when cash is received or paid. This implies that in the accrual case the benefits of certain activities are matched with the resource consumption needed for these activities. Consequently, $\mathrm{CB}$ and $\mathrm{AB}$ may diverge with regard to resource creation (receipts vs revenues) as well with regard to resource consumption (expenditures vs expenses). At first we illustrate possible deviations of the discussed budgeting modes on the revenue side, and subsequently on the expenses side. It has to be acknowledged that CB and its related budgetary accounting is often much more than just a registration of intended cash inflows and outflows per budget article, because it distinguishes between three steps in registering transactions: a registration of the planned cash revenues and expenditures (appropriations), the commitments, and the actual receipts and expenditures at the time transactions occur (see, for instance, Christiaens and Neyt, 2015, p. 31).

\section{Revenues}

Important revenue categories of PSOs are taxes, service charges and transfers from other governmental layers (for example, from central to intermediate or local government).

Budgeted cash revenues are the expected receipts in a certain period, often a year. However, a part of these incoming cash flows relate to the previous year. In accrual terms, this part is recorded as accounts receivable at the year-beginning. In a similar vein, a part of the expected revenues of the current year will be received in the next year, which is recorded as accounts receivable at the year-end.

Now we can give the following definition:

Budgeted accrual revenues are budgeted cash revenues in the 'budget year' less the estimated accounts receivable at the year-beginning, plus the estimated accounts receivable at the year-end.

So, under what circumstances do accrual revenues diverge from cash revenues? When accounts receivable substantially decrease or increase over the year. This implies that for governments with well-organised and stable processes of income generation, $\mathrm{CB}$ and $\mathrm{AB}$ revenues are not expected to diverge much. ${ }^{5}$ The latter conclusion cannot be drawn for expenditure/expenses, where the $\mathrm{CB}-\mathrm{AB}$ differences are more fundamental, as will be shown now. 
Why Cash-Based Budgeting Still Prevails in an Era of Accrual Reporting in the Public Sector

\section{Expenditures/Expenses}

Budgeted expenditures are the expected payments in a certain period, usually a year. Budgeted expenses (this is an accrual term for consumption of resources) can be different from expenditures (equal to cash outflow). The three following factors are considered to be the main causes for differences between $C B$ and $A B$, although, in practice, an array of other factors may also impact: ${ }^{6}$

- Fixed assets: under CB the payments for purchasing fixed assets (such as infrastructure assets for roads and bridges) are recorded, while under $A B$ the depreciation of all assets in use is recorded, where depreciation is the loss in value during the year of use of the fixed assets. If the purchase pattern of fixed assets is irregular over the years (for example, through large purchases in one year, and no or minimal purchases in some subsequent years), $\mathrm{CB}$ and $\mathrm{AB}$ will lead to significantly different outcomes. $A B$ will show a much more stable pattern of resource consumption over the years than $\mathrm{CB}$. However, if investments are more even between years, capital expenditures (under $\mathrm{CB}$ ) and expenses (under $\mathrm{AB}$ ) can be relatively similar.

- Provisions are obligations for payments in the future which originate in a transaction in the current year, while the exact value of these obligations is uncertain and has to be estimated. An example relates to pension provisions where the PSO has to pay pensions to its employees retiring in the future. Under CB there are no provisions, and pension payments in the current year are booked as outgoing cash flows. In contrast, under $\mathrm{AB}$ the yearly estimated future obligation for paying pensions will be recorded as an expense, while the actual paid pensions in the current year are deducted from the provisions' account. So, if payments in the current year are quite similar to estimations of future payments related to the current year, $\mathrm{CB}$ and $\mathrm{AB}$ come to similar financial outcomes. However, if, for example, staff numbers have decreased substantially in the recent past, current payments will be higher than obligations for future payments, and $\mathrm{CB}$ and $\mathrm{AB}$ give rise to diverging outcomes. Moreover, if a PSO starts to include its future pension obligations as a provision under $A B$, it will need to pay its current pensioners and create a provision relating to future pensioners, an action that will result in an ongoing double burden.

- Accounts payable are debts originating in the current year (relating to resource consumption) which will lead to payments in subsequent years. An example is the production of certain services (like waste water treatment or museum exhibitions) which requires purchase of energy, for which payments are not chronologically corresponding to resource consumption in the production process. This leads to similar accrual corrections as for revenues: resource consumption under $A B$ in a certain year is equal to budgeted payments for these resources in this year (this is the expenditure under $\mathrm{CB}$ ) less estimated accounts payable at the year-beginning plus estimated accounts payable at the year-end. Consequently, if payables are relatively stable over time, $\mathrm{CB}$ and $\mathrm{AB}$ result in similar outcomes regarding the financials of resources consumed. ${ }^{7}$ 
All in all, a fundamental and material difference between $\mathrm{CB}$ and $\mathrm{AB}$ is the treatment of fixed assets. The other causes of differences - provisions and accounts payable can also be influential, but probably their impact is often relatively less substantial, particularly if, in the case of pension provisions, staff numbers are stable over time.

After having pointed to the main causes of differences between $C B$ and $A B$, it is worthwhile to realise that $A B$ requires more additional administrative actions compared to CB. A few examples can illustrate this. First, some general purpose fixed assets, such as office assets, will lead to depreciation expenses which have to be attributed to all work spots and related budget articles. Second, accrued interest expenses have to be attributed based on the book values of the fixed assets of the budget articles. Finally, there are various options for using $A B$ in a decentralised governmental organisation with, for instance, agencies: on the one hand, funding agencies' full costs (cash-in-hand), i.e. including depreciation, which means a loss of central control of investments, and on the other hand funding only agencies' cash elements (no-cash-in hand), and separate control of non-cash items (depreciation of investments), which implies that the cash system largely remains (see further Blöndal, 2004, pp. 107-110).

\section{THE PROS AND CONS OF CASH BUDGETING AND ACCRUAL BUDGETING}

After demonstrating that many governments combine cash for budgeting and accruals for reporting, and having explored the circumstances for such a combination, we now address the core of our paper. Here we critically assess the arguments for retaining a cash basis for budgeting against a transition to accruals for budgeting. Obviously, most of the pro arguments for $\mathrm{CB}$ are at the same time contra arguments for $\mathrm{AB}$ (and vice versa). To avoid duplication, we abstain from repeating arguments for one mode of budgeting which already have been presented with regard to the other mode. The arguments we are discussing here are principally focused on budgeting, although the quite narrow interrelations between budgeting and reporting (in our case, of accrual reporting) should not be ignored. The discussion is based on a comprehensive literature review.

\section{Arguments in Favour of Cash Budgeting}

At first we discuss several arguments found in the reviewed literature with regard to the relative preference of the $C B$ mode compared with the $A B$ mode, implicitly or explicitly in the framework of an existing accrual system. We do not refer to the fundamental debate about the general applicability of accrual accounting in the public sector which took place in the last decades (see, for example, Monsen and Näsi, 1998).

\section{Money Is Core}

The most striking, and also most often used, argument is that CB is a concept allowing easy and well-functioning planning and control of monetary spending of government. For centuries, governments used to formulate and execute a budget 
Why Cash-Based Budgeting Still Prevails in an Era of Accrual Reporting in the Public Sector

covering all expenditures and all revenues expected for the budget year. Comparing cash-based appropriations with the actual cash outflow is easy and clear in this case (Robinson, 2009; Warren, 2015). In contrast, in the case of AB the control of spending by the Ministry of Finance (or another responsible ministry) would be more ambiguous because sector departments have more discretion to determine their expenses (for example, regarding to depreciation of assets). Therefore, the risk of overspending may be higher in the AB case than in the CB case (Blöndal, 2003). A related argument is that the $\mathrm{CB}$ concept is more clearly focused on the authorisation function of the budget: the legislation authorises the government to spend certain expenditures (Bergmann, 2009, p. 66).

\section{Assessment}

A clear and strict focus on monetary spending within the given framework of the budget is doubtless a central feature of a budget. In principle, an $\mathrm{AB}$ can also inform about cash-based items (see below for details). This is, however, contestable as the information quality very much depends on how cash-based information is structured in such an AB. For instance, does cash information follow the various line items of the budget or is it offered in an aggregated mode (for example, summarised operational cash flow and investment cash flow)? The AB can obviously have a higher risk of overspending because expense control may be less straightforward.

\section{Consistency with Fiscal Policy}

As the fiscal policy of a government is usually formulated according to cash terms (for example, with regard to national debt or future tax policy), it is obvious that a CB is more in line with such policies than an AB (Blöndal, 2004; Robinson, 2016). In recent times, international organisations like the International Monetary Fund (IMF), and also national governments, have developed new tools for increasing fiscal transparency. For example, long-term fiscal sustainability reports and medium-term expenditure frameworks which are cash-based and allow forecasting of the future financial development of the state have been utilised (Robinson, 2009, 2016). An argument against $A B$ in this context is that such an approach may not be consistent with existing budget legislation and budget rules (which, for example, provide deficit limits) (Warren, 2015, p. 122). Changing such rules may be costly and time-consuming. Additionally, some critical observers are concerned that the move to accruals may shift the central budgetary focus from compliance to more general issues of performance (Carlin and Guthrie, 2003, p. 154).

\section{Assessment}

It is true that fiscal policies are to a large extent dealing with future monetary issues (like the taking on of debt or the raising of tax revenues). An $\mathrm{AB}$ is, at the first glance, less tailored to such issues. On the other hand, accrual data serve a medium-term and long-term perspective with respect to state finances, as they identify future challenges of financing re-investments in infrastructure or of paying pension benefits to civil servants. We also have to be aware that important macroeconomic statistical systems such as the European System of National and Regional Accounts (ESA) are composed on an accrual base, although such systems still have a strong focus on 
important cash items (see below). All in all, the CB can be considered an appropriate information source about fiscal sustainability, meaning that government can repay its debts, operationalised by a sufficient low level of budget deficits. AB, including depreciation of fixed assets, cannot contribute to this goal. Alternatively, however, the net financial debt, which is defined as liabilities minus financial assets, can be used under $\mathrm{AB}$ as a ratio to assess the accomplishment of the fiscal policy goal of a PSO (Robinson, 2009).

\section{Understandability and Complexity of Budgeting Concept}

A widely used argument for CB is its comprehensibility, which is considered particularly relevant for politicians involved in the budgeting process. Cash as the 'language' of the CB seems to be a clear and unambiguous denominator, and politicians, as well as a range of other relevant stakeholders, can understand it and communicate about its attribution to certain government policies (Carlin and Guthrie, 2003, p. 157). In contrast, AB requires more sophisticated accounting and budgeting knowledge and skills, not only from politicians but also from public servants. There is evidence that elected politicians are not much interested in accruals (PricewaterhouseCoopers, 2015; Moretti, 2016). As a result, in the AB case budgetary power may shift from elected politicians to professionals and accounting experts, which may weaken the democratic control of government (Schick, 2007, p. 134). Furthermore, some observers indicate that $\mathrm{AB}$ may only work if the involved managers dispose of sufficient operative discretion to take decisions, for example with regard to valuation of assets or other accrual items within the process of budget formulation (Schick, 2007, p. 131). And finally, because of higher complexity of the AB, the whole budgeting process may be overloaded and a timely budget decision may be at risk (Warren, 2015, p. 121).

\section{Assessment}

This is a quite uncontestable argument. The CB is easy comprehensible and can be used by politicians and bureaucrats without deeper and more demanding accounting knowledge. Additionally, some other prerequisites of the accrual logics have to be taken into account. While balancing a CB is a clear fact (expected cash inflow against cash outflow), an accrual budget balance is a more complex and ambiguous issue: the $\mathrm{AB}$ not only has to cover all expenditures in the budget year but additionally also non-cash expenses like depreciation. This makes budget balancing not only more difficult to achieve but also less comprehensible. On the other hand, the relative simplicity of the $\mathrm{CB}$ mode should not hide the fact that the focus on cash transactions without recognising the activities 'behind' the cash flow can provide a partly inappropriate picture of resource creation or consumption (see further discussion below). Furthermore, decision makers are in the CB\&AR case anyway, forced to become acquainted to some extent with accruals, although less with a view on the budget.

\section{Risk of Budget Manipulation}

Some experts consider a $\mathrm{CB}$ as less vulnerable to manipulation than an $\mathrm{AB}$. In the latter case, governments or single departments have quite remarkable discretion as 
Why Cash-Based Budgeting Still Prevails in an Era of Accrual Reporting in the Public Sector

to how to assess the future development of, for instance, the value of assets or interest rates (Government Accountability Office, 2000; Khan, 2013, p. 354).

\section{Assessment}

This judgement is quite contested, as opponents suggest even higher opportunities for manipulation in the case of $\mathrm{CB}$, for example by pushing up or postponing payments (Diamond, 2002, pp. 6-7). All in all, we think that manipulation of budgets is always possible to some extent, irrespective of the application of $\mathrm{CB}$ or $\mathrm{AB}$, even if such manipulation may be less easy to detect or to prevent in the case of $A B$.

\section{Low Costs}

Obviously, if a government decides for the CB\&AR mode it has to reform the reporting system. However, it can continue to use the already existent $\mathrm{CB}$. The total costs of system change, of qualifying involved staff and other stakeholders, and of operating the reporting and budgeting system will be lower if $\mathrm{CB}$ is maintained than if the budgeting system is also changed (Robinson, 2016, p. 36). Thus, from a valuefor-money perspective it may be questioned if the additional costs of transforming the budgeting system - in the case of an already existing accrual reporting system - from $C B$ to $A B$ are justified. On the other hand, continuing $C B$ while applying accrual reporting is also costly, because the government has to operate two parallel accounting systems: the accrual reporting and a cash-based budgetary reporting. However, the usefulness of budgeting change has to be judged also with regard to its expected benefits. Are the whole efforts worth it if the differences between both budget types are quite marginal? Schick (2007, p. 135) for instance refers to New Zealand's budget of 2004, where the difference between cash-based and accrualbased revenues was only about 0.8 per cent.

\section{Assessment}

The cost efficiency of the $\mathrm{CB}$ mode compared to the $\mathrm{AB}$ mode is debatable. There are certainly costs of the reform process which could be avoided when maintaining the CB mode. The bulk of these costs are, however, caused by transforming the reporting system (for example, with respect to the valuation of assets). Second, some additional costs of operating a more complex $\mathrm{AB}$ concept instead of a $\mathrm{CB}$ system can be expected. Such costs have to be offset against the costs of running two parallel accounting systems (see above). Finally, we doubt that the differences between $\mathrm{CB}$ and $\mathrm{AB}$ will always be as marginal as indicated in the New Zealand case above. We rather assume that the differences will be considerably higher at the expenditure/expenses side of the budget, because here depreciation and other expenses are in most cases quite different from the cash outflows related to them.

\section{Arguments in Favour of Accrual Budgeting}

In this subsection we present arguments favouring the $\mathrm{AB}$ mode in comparison to the $\mathrm{CB}$ mode, again assuming that this budgeting concept is incorporated in an accrual accounting system (see also Blöndal, 2004; Cortes, 2006). 


\section{Consistency of Budgeting and Reporting System}

In the AB\&AR mode both parts of the financial management system of a government are aligned with one another and follow the same accounting logic (Lüder, 1999). This makes comparisons between the budgeted and the realised figures easier and more plausible: having 'system consistency pays-off in the long run' (Bergmann, 2009 , p. 66). The harmonisation and consistency of reporting and budgeting is seen as a benefit. In a recent survey of German public financial management experts in the context of the European Public Sector Accounting Standards (EPSAS) debate, the majority of respondents were clearly in favour of a parallel change of reporting and budgeting (Wüstemann, Wüstemann and Conrath-Hargreaves, 2016).

\section{Assessment}

From an accounting viewpoint this argument is certainly relevant. If a government has introduced accrual reporting, it is coherent to change the budgeting concept accordingly. However, this argument becomes less important when the structure of the cash budget does not resemble the structure of the accrual-based income statement, which is often the case. Then budget execution reports follow the structure of the cash budget. Evidently, reconciliation adaptations are needed at the end of the year for comparing the end-of-year budget execution report with the income statement.

\section{Compatibility of AB with Current Macroeconomic Statistical Systems}

The macroeconomic national accounts - for example, those stipulated for the member states of the European Union (EU) - are mostly based on modified accruals. This is the case with the EU Stability and Growth Pact (Khan, 2013, p. 349) and with the Government Finance Statistics (GFS) of the IMF (Schick, 2007, p. 133). A national budget following the accrual mode can therefore be easier and more consistently translated into the respective national fiscal statistics. Such a common database also improves the comparability of financial accounts of countries in Europe and in other parts of the world (which is also the aim of current homogenisation strategies in public sector accounting as discussed in the actual debate of EPSAS; see, for instance, Aggestam Pontoppidan and Brusca, 2016).

\section{Assessment}

Generally, this argument is plausible, although the data necessary for such statistical systems can also be provided separately. And the above discussion about the consistency of $\mathrm{CB}$ with fiscal issues has to be considered here as a counter argument.

\section{AB Provides Comprehensive Information about Full Costs}

$\mathrm{The} \mathrm{AB}$ can facilitate the calculation of the full costs of government activities (for example, programmes or services), because not only cash-related transactions but also non-cash resource consumption (like depreciation of assets) is included (Blöndal, 2004). Some future obligations, like quasi-liabilities related to long-term public-private partnership contracts, are only recognised in the AB (Khan, 2013, p. 353). The medium-term, and to some extent long-term, perspective of the $A B$ ensures more intergenerational equity, as we discussed above in the case of pension 
Why Cash-Based Budgeting Still Prevails in an Era of Accrual Reporting in the Public Sector

provisions (Schick, 2007, p. 117). This may result in a strengthened accountability of the respective government, because budget managers are responsible for the total costs of their programmes and services (Warren, 2015, p. 117).

Not all future obligations are, however, covered by the AB. Certain long-term commitments like social insurance benefits are often not recognised in the $A B$, because their character as government obligation is debatable, a factor which reduces the significance of this type of budgeting (Government Accountability Office, 2007). Apart from this, the AB allows a broader view on resource allocation: this mode is not only focused on the creation and consumption of one single kind of resource (cash), but covers also other types of resources. Additionally, AB ensures a better control of the liabilities of PSOs, including contingent liabilities, such as provisions (Robinson, 2016, p. 37).

\section{Assessment}

The quality of accrual data is doubtless higher compared to cash data. As has been said, the picture of the financial situation is more complete and broader in the $A B$ case than in the CB mode.

\section{Risk of Budget Manipulation}

In contrast to the above mentioned argument, several experts argue that the $A B$ may be less affected by manipulation, because accrual systems usually follow commonly recognised international accounting (and budgeting) standards (like IPSAS) which limit manipulation opportunities (Diamond, 2002). Additionally, it is argued that manipulation opportunities are generally higher in the $\mathrm{CB}$ case as managers can easily anticipate or postpone cash-related decisions, for example, with regard to the procurement of assets (Warren, 2015, p. 125).

\section{Assessment}

This argument has already been assessed before (see above). It is a contested argument, because both systems, $\mathrm{AB}$ and $\mathrm{CB}$, are vulnerable to data manipulation.

\section{AB Usually Also Includes Cash Data}

Proponents of the CB mode sometimes create the impression that there is an 'either/ or' option (either only accrual data or only cash data). The reality is often different. Most practical cases of an $\mathrm{AB}$ show that such concepts do not only include accrual figures but also cash data, for instance in a cash flow forecast. There is clear evidence that $\mathrm{AB}$ concepts provide information about the resource consumption as well as about the cash inflow and outflow (for example, in the UK and in Austria: Marti, 2013, p. 35). Thus, deciding to use accrual budgeting does not mean cashbased information cannot be used or accessed. The CB/AB choice is instead the question of the more dominant perspective of budgetary decision-making: is it the accrual-based 'operations plan' (in the logic of an operations or income statement) or is it a 'payment plan' according to the logic of a cash flow statement? However, to answer this question is difficult, as it needs empirical evidence from the study of budgetary decision-making processes in governments having applied the AB concept. Such types of investigation are rarely available. 


\section{Assessment}

This is certainly a plausible point. If the $\mathrm{AB}$ also provides important aspects of the monetary situation of government, there is little reason to argue against it. However, it is questionable which type of cash information is provided under AB. If reporting is not in line with the budget structure, then relevant information for budget control is not available.

\section{Empirical Experiences with Accrual Budgeting}

While there is extensive experience with cash budgeting by various governments over decades which is discussed at length in numerous critical reflections of this budgeting mode, the evidence of $A B$ practices is relatively limited due to the quite recent implementation of this budgeting mode (see also the earlier section on the 'Empirical Picture'). Some observers find that, in general, the experiences with $\mathrm{AB}$ seem to provide only modest, and sometimes even disappointing, advantages. Because of the various prerequisites (well-trained staff, sufficient information technology support, etc.), the $\mathrm{AB}$ mode is considered to be appropriate only 'for the small cohort of best managed governments' (Schick, 2007, p. 137).

Problems are particularly identified with respect to non-cash transactions, such as depreciation and capital charges (Monteiro and Gomez, 2013, p. 106; Robinson, 2016 , p. 38). Several researchers observe that after the formal introduction of $A B$ the majority of involved government staff continue using cash data for decision making (Monteiro and Gomez, 2013, p. 108; Robinson, 2016, p. 37). Furthermore, even the practice of accrual reporting appears to be weakened if $A B$ does not work as expected. This is perhaps unsurprising: budgeting, as the politically much more important financial management tool, determines to a great extent financial reporting. If it remains in a cash-based position, the adjacent reporting system will likely follow the same logic. Carlin and Guthrie (2003) draw conclusions from the Australian experience with $\mathrm{AB}$ : introducing $\mathrm{AB}$ is much more than a technical exercise, it must be seen in connection with broader public management reform concepts like the strengthening of market mechanisms and contracting out. In such cases, PSOs may embrace producing a full-cost budget, as they need sufficient resources for efficient in-house production or for contracting out its provision to external providers.

\section{CONCLUSIONS AND DISCUSSION}

The basic aim of this paper is to understand the rationale of reform decisions made by various governments with regard to their reporting and especially budgeting systems. From previous studies it appears that about one-third to half of governments in industrialised countries changed their reporting system during the last decades from traditional cash to accruals, while continuing to use cash budgeting. At least from an accounting perspective such inconsistency of financial management logics appears to be inappropriate, and it may be asked why governments decide to use such a combination of divergent concepts.

In our literature review we found various arguments in favour of and against the combination of cash budgeting and accrual reporting (which were discussed 
Why Cash-Based Budgeting Still Prevails in an Era of Accrual Reporting in the Public Sector

and assessed in the previous section). Summarising the various arguments, we think that the following issues have been most influential on the decisions of governments to continue $\mathrm{CB}$ while moving to AR:

- Cash is perceived as a clear language and unambiguous denominator for the budget of a state or any PSO which is easy to understand and to communicate.

- Major actors have long experience in using CB. Various routines in the procedures of budget formulation, execution and control are well established and follow long-standing traditions.

- The interrelations of the annual CB with the medium- and long-term fiscal policy of the respective governments are perceived as being transparent and unambiguous.

- As accrual reporting is in use, the government gets a sufficient picture of the full resource consumption at least ex post, via the financial reporting. Thus, the CB\&AR mode combines the cash-based spending focus with the resourcebased reporting focus.

- Reformers are critical about the additional costs of a system change from cash to accrual budgeting and they believe that the change is not worth the effort.

In contrast to these points, the critical debate on the insufficiency of $\mathrm{CB}$, and on the benefits of $A B$, has proved to be less relevant and influential. As a result, various governments have decided to stay with $\mathrm{CB}$ in their budgeting systems.

For the evaluation of the CB\&AR mode, we consider the following aspects as relevant. At first it may be asked, how divergent are $C B$ and $A B$ in reality? Our review of the literature indicates that $\mathrm{CB}$ and $\mathrm{AB}$ are different, but their differences should not be exaggerated. In the case of labour-intensive activities, especially regarding policy making and policy oversight, expenditures (cash-based) are almost identical to expenses (accrual-based). However, when activities require substantial amounts of capital, as for public infrastructure or services delivery, $\mathrm{CB}$ and $\mathrm{AB}$ can lead to diverging outcomes, because of budgeting for capital investments and depreciation respectively. This also explains why in some countries, such as the Netherlands, CB is used for labour-intensive core government, while agencies, which often combine labour and capital resources, are applying AB (Budding and van Schaik, 2015). It may be, therefore, a pragmatic solution to request the $A B$ mode only from PSOs with a strong and fluctuating non-cash resource consumption, and to allow other types of PSOs (and for the 'whole of government' finances) to stay with CB.

Second, we observe that, when governments are combining cash for budgeting with accruals for reporting, the two are not (or only to a limited extent) connected with each other. In a more general sense, budgetary documents are structured according to programmes, functions or organisational units, and the follow-up of those budgets in the budget execution reports is structured in the same way. In contrast, the financial reporting documents, especially the income statements, are structured along expense categories (for example, salaries and depreciation) and revenue categories (for example, taxes and grants). This means that budgeting and reporting documents are generally largely decoupled with regard to their internal 
structures. Consequently, in both modes $(\mathrm{CB}$ and $\mathrm{AB})$ there is the need for a separate budgetary reporting which follows the budget structure.

In this context we have to be aware that - as already indicated before - politicians are mainly interested in budgetary affairs including appropriations and comparing actual and budgeted appropriations. In contrast, accrual information in reports only receives little attention, irrespective of whether budgeting is cash- or accrualbased. However, evidently, one difference remains: the reconciliation between the end-of-year budget execution report and the income statement is straightforward and easily accomplishable under $\mathrm{AB}$, while it requires various end-of-year adaptations under CB.

Third, in the debate about the pros and cons of accrual budgeting, it should also be recognised that $\mathrm{AB}$ requires a higher professionalisation of financial management staff, because it is based on a more advanced accounting system and such staff need considerable expertise. Moreover, layperson politicians, as important users of budget information, often lack the skills for proper interpretation of the more advanced accrual information because of issues such as depreciation, provisions and deferred transactions. Sufficient training is therefore an important prerequisite of introducing $\mathrm{AB}$.

Fourth, there is evidence that the $A B$ mode will only work if budget managers have sufficient discretion. In the relationship between the executive and the legislature, the former is mandated by the latter in the budgeting process to spend amounts of money according to budgeted totals per budget unit. The legislature is the budget authority and the executive is the budget receiver. This mandate is clear and quite unambiguous in the case of cash budgeting: cash payments per programme or function can be made by the executive up to the ceilings approved by the legislature. This mandate is, however, much more ambiguous under accrual budgeting (see, for example, Bergmann, 2009, p. 66). In this case, the spending ceiling gives the budget receiver more discretion in combining cash and non-cash elements (such as salaries and depreciation) according to its own judgement. The increase of discretion results in a transfer of accountability from the budget authority to the budget receiver. Consequently, the legislature has to show more trust in the judgmental abilities of the executive under $\mathrm{AB}$ than under $\mathrm{CB}$ - and this trust must be justified in practice. Put differently, $\mathrm{AB}$ implies broader spending mandates at the executive part than $\mathrm{CB}$.

In a similar vein, $A B$ requires broader spending mandates between core ministries (as budget authorities) and their agencies (as budget receivers) compared to CB. Blöndal (2004), for example, argues that two options for the funding of agencies are possible. One is the 'cash-in-hand' option, which is a funding of the agencies' full costs, including resources for depreciation. This may result in a loss of central control of investments. The other option is an exclusive funding of cash elements ('no-cash-in-hand') and a separate control of non-cash items (depreciation of investments), which implies a constrained autonomy for agencies and substantial central control, and actually means that the cash system (at least to some extent) remains. In a similar way, cumulative depreciations of agencies can be handled: either these agencies can be allowed to re-invest their accumulated depreciations (which means high agency autonomy and constrained central control) or agencies' investments require central guidance and approval (resulting in limited agency autonomy and 
Why Cash-Based Budgeting Still Prevails in an Era of Accrual Reporting in the Public Sector

strong central control). Summing up, we conclude that the advantageousness of the $\mathrm{AB}$ mode is dependent on several contextual conditions of the respective public sector systems which have to be carefully examined before starting such reforms.

As a result of this debate we conclude that in most cases a stepwise adoption of accrual elements in the budget is recommended. The motto should be 'first things first and keep it simple' (see also Hyndman, 2016). For example, depreciation of business assets should be done before the more contested valuation and eventual depreciation of other types of assets (for example, community assets and heritage assets). Another option should be the implementation of $A B$ in those governmental domains where its potential added value is the highest (possibly agencies first and core government not, or at a later stage). Evidently, a gradual and partial adoption of accrual elements in budgeting has implications for reconciliation with the accrual-based income statement at year-end (more adjustments are needed than in a fully accrual-based budget). These recommendations may be particularly important to less developed countries, which often suffer from a lack of quality regarding their accounting systems and accounting expertise (see also Diamond, 2002).

The theme of this paper was related to the reasons for preferring the cash versus the accrual mode of budgeting. Thus, the analytical focus was directed to the type of accounting material for budgeting purposes: should this material or data be based on cash flows or should it cover also non-cash data (as used by the accrual mode)? This issue is, however, only one perspective of budgeting reforms. As we indicated before, there are several variables which can (and should) be subject to public budgeting reforms. Possibly one of the most important issues to be addressed relates to the inclusion of information on targets, outputs and outcomes in the budget (performance budgeting; see Mauro, Cinquini and Grossi, 2016 for a literature review). Another improvement would be to expand the time frame of the budget, and move from an annual to a multi-annual budget, and to link it with medium-term expenditure frameworks. Other relevant issues to be considered relate to the possibility of increasing opportunities for a flexible budget execution: shifting among items; or carrying over of unspent appropriations; or the redirection of the process of budget formulation from the traditional bottom-up to a top-down perspective. These examples of budgetary reform issues illustrate the complexity of budget innovations and relativise the importance of the CB\&AR mode.

A further reflection regards the stakeholder perspective on accounting information. Our user perspective was almost exclusively constrained to politicians and public sector managers. Given this perspective, we tried to assess the pros and cons of cash-based and accrual-based budgeting. However, additional stakeholders using accounting information in the public sector can be relevant. For example, creditors and credit agencies, or oversight bodies, may have a primary interest in accrual types of accounting information related to the financial health of a PSO, particularly with respect to ratios like equity over total liabilities, or the extent of financial surplus over costs. This implies that a PSO may need different accounting systems - cash- and accrual-based - serving different purposes and related stakeholders. This, however, does not undermine the importance of discussing the most relevant accounting basis for budgeting purposes - cash or accrual - for its main stakeholders (politicians and public sector managers). 
A main issue for future research is how to explain the reasons why several sets of countries have adopted diverging budgeting and reporting modes. By taking Lüder's contingency framework of financial management reforms in the public sector as a starting point (see, for example, Lüder, 2002), several groups of variables are expected to be influential. These include different doctrines for ruling the public sector (such as New Public Management (NPM) versus Neo-Weberian thinking); certain reform drivers (for example, the ideas of specific professional groups like accountants and consultants); political promotors of reforms (like the Ministry of Finance, or the audit institution). In addition, political or financial scandals can be drivers for certain changes. Just listing these groups of variables is, however, insufficient. It will be challenging to relate different values of each of these variables to diverging budgeting and reporting modes. For example, it is possible that a strong NPM perspective, combined with influential professional bodies of accountants adhering to business accounting (such as in the UK), could be drivers for the AB\&AR mode. However, where there is less pronounced embracing of NPM thinking, and stronger traditions of bureaucratic administration, such as in France, this could explain the adoption of a CB\&AR mode. In addition, it can be expected that long-lasting traditions of cash-based governmental standards setting (as in German and Dutch central government), could be an obstacle for adopting accrual standards for budgeting and reporting.

In a nutshell, we would like to conclude our observations and reflections on the issue of why many governments opt for accrual accounting for reporting, but not for budgeting, and thus continue to use cash budgets. At first glance, this mode of financial management appears quite inconsistent and contradicting. However, from a more nuanced perspective, the combination of cash budgeting and accrual reporting can be seen as an acceptable compromise. It can be defended through the lens of a fundamental budgeting logic that identifies all expenditures and revenues expected for the budget year, and sees the comparison between cash-based appropriations and actual cash outflows as an easy and straightforward control mode. Moreover, this combination aligns with the dominance of budgeting over reporting and the limited accounting expertise of many accounting information users (often public sector managers and, especially, politicians). The ultimate transfer from cash to accruals in budgeting needs to be based on a solid assessment of its added value to these users, and not due to the pressures of accounting experts.

\section{ACKNOWLEDGEMENT}

The authors are grateful to Johan Christiaens and Ron Hodges, as well as Noel Hyndman, editor of the Accounting, Finance and Governance Review, for their comments on earlier versions of this paper.

\section{ENDNOTES}

Our empirical picture relies to a large extent on Brusca, Caperchione, Cohen and Manes Rossi (eds) (2015), Public Sector Accounting and Auditing in Europe: The Challenge of Harmonization, Basingstoke: Palgrave 
Why Cash-Based Budgeting Still Prevails in an Era of Accrual Reporting in the Public Sector

Macmillan (quoted as Brusca et al., 2015a). This book offers an abundance of evidence on fourteen European countries; its last chapter (quoted as Brusca et al., 2015b) provides a comparative summary of these findings. We also refer to Jones et al. (2013) for a comparative study on budgeting and reporting practices in the central governments of France, Germany, the United Kingdom and the United States.

2 We would like to show our gratitude to our colleagues Caroline Aggestam Pontoppidan (Denmark), Isabel Brusca (Spain), Johan Christiaens (Belgium), Sandra Cohen (Greece), Susana Jorge (Portugal) and Marine Portal (France). We also thank Francesca Manes Rossi for clarifying the complex budgeting and accounting mode in her country, Italy.

3 Apart from these European countries, also the European Commission (EC) itself follows this mode; the EC applies accrual accounting (IPSAS) but uses a modified cash budgeting system (European Commission, 2014, p. 262).

4 The only exception is Flemish local government where budget and income statement structures match and are thus comparable.

5 We acknowledge that, in addition to regular revenues, also extraordinary revenues, such as the sale of assets, can be at stake.

6 For example, loans and debts, interest payments versus accrued interest expenses, saved interest payments due to equity, pre-paid expenditures and pre-received income (see for some further explorations: Blöndal, 2004, pp. 107-116; Budding and van Schaik, 2015, pp. 146-152). In addition, the valuation of fixed assets, i.e. the preferences for either a historical or some kind of future value, is a contested issue, and also the question as to which assets have to be valued and depreciated, for instance economic versus community assets (van Helden and Hodges, 2015, Chapter 5).

7 If the use of materials is at stake, somewhat similar registrations have to be made: the use of materials under accrual budgeting is related to the expected production activities; if the use is higher (lower) than the purchase of materials, this will be seen in a decrease (increase) in the stock of materials.

\section{REFERENCES}

Aggestam Pontoppidan, C. (2015). Public Sector Accounting and Auditing in Denmark, in I. Brusca, E. Caperchione, S. Cohen and F. Manes Rossi (eds), Public Sector Accounting and Auditing in Europe: The Challenge of Harmonization, pp. 42-59, Basingstoke: Palgrave Macmillan.

Aggestam Pontoppidan, C. and Brusca, I. (2016). The First Steps Towards Harmonizing Public Sector Accounting for European Union Member States: Strategies and Perspectives, Public Money and Management, Vol. 36, No. 3, pp. 181-188.

Anessi Pessina, E., Barbera, C., Sicilia, M. and Steccolini I. (2016). Public Sector Budgeting: A European Review of Accounting and Public Management Journals, Accounting, Auditing \& Accountability Journal, Vol. 29, No. 3, pp. 491-519.

Bergmann, A. (2009). Public Sector Financial Management, Harlow: Pearson Education.

Blöndal, J.R. (2003). Accrual Accounting and Budgeting: Key Issues and Recent Developments, OECD Journal on Budgeting, Vol. 3, No. 1, pp. 43-59.

Blöndal, J.R. (2004). Issues in Accrual Budgeting, OECD Journal on Budgeting, Vol. 4, No. 1, pp. 103-119.

Brusca, I., Caperchione, E., Cohen, S. and Manes Rossi, F. (eds), (2015a). Public Sector Accounting and Auditing in Europe: The Challenge of Harmonization, Basingstoke: Palgrave Macmillan.

Brusca, I., Caperchione, E., Cohen, S. and Manes Rossi, F. (2015b). Comparing Accounting Systems in Europe, in I. Brusca, E. Caperchione, S. Cohen and F. Manes Rossi (eds), Public Sector Accounting and Auditing in Europe: The Challenge of Harmonization, pp. 235-251, Basingstoke: Palgrave Macmillan.

Brusca, I., Montesinos, V. and Vela, J.M. (2015). Public Sector Accounting and Auditing in Spain, in I. Brusca, E. Caperchione, S. Cohen and F. Manes Rossi (eds), Public Sector 
Reichard and van Helden

Accounting and Auditing in Europe: The Challenge of Harmonization, pp. 173-188, Basingstoke: Palgrave Macmillan.

Budding, T. and van Schaik, F. (2015). Public Sector Accounting and Auditing in the Netherlands, in I. Brusca, E. Caperchione, S. Cohen and F. Manes Rossi (eds), Public Sector Accounting and Auditing in Europe: The Challenge of Harmonization, pp. 142-155, Basingstoke: Palgrave Macmillan.

Buylen, B. and Christiaens, J. (2016). Talking Numbers? Analyzing the Presence of Financial Information in Councilors' Speech During the Budget Debate in Flemish Municipal Councils, International Public Management Journal, Vol. 19, No. 4, pp. 453-475.

Carlin, T. and Guthrie, J. (2003). Accrual Output Based Budgeting Systems in Australia: The Rhetoric-Reality Gap, Public Management Review, Vol. 5, No. 2, pp. 145-162.

Christiaens, J. and Neyt, S. (2015). Public Sector Accounting and Auditing in Belgium, in I. Brusca, E. Caperchione, S. Cohen and F. Manes Rossi (eds), Public Sector Accounting and Auditing in Europe: The Challenge of Harmonization, pp. 27-41, Basingstoke: Palgrave Macmillan.

Cohen, S. (2015). Public Sector Accounting and Auditing in Greece, in I. Brusca, E. Caperchione, S. Cohen and F. Manes Rossi (eds), Public Sector Accounting and Auditing in Europe: The Challenge of Harmonization, pp. 108-124, Basingstoke: Palgrave Macmillan.

Cortes, J.L. (2006). The International Situation vis-à-vis the Adoption of Accrual Budgeting, Journal of Public Budgeting, Accounting \& Financial Management, Vol. 18, No. 1, pp. 1-26.

Diamond, J. (2002). Performance Budgeting-Is Accrual Accounting Required?, working paper IMF WP 02-240.

European Commission (2014). European Union Public Finance, fifth edition, Brussels: European Commission.

Government Accountability Office (US) (2000). Accrual Budgeting: Experiences of Other Nations and Implications for the United States, Washington, DC: GAO.

Government Accountability Office (US) (2007). Budget Issues: Accrual Budgeting Useful in Certain Areas But Does Not Provide Sufficient Information for Reporting on Our Nation's Longer-Term Fiscal Challenge, Washington, DC: GAO.

Helden, G.J. van and Hodges, R. (2015). Public Sector Accounting and Budgeting for NonSpecialists, Basingstoke: Palgrave Macmillan.

Hyndman, N. (2016). Accrual Accounting, Politicians and the UK - With the Benefit of Hindsight, Public Money \& Management, Vol. 36, No. 7, pp. 477-479.

International Federation of Accountants, Public Sector Committee (2000). Government Financial Reporting: Accounting Issues and Practices, Study 11.

Jones, R., Lande, E., Lüder, K. and Portal, M. (2013). A Comparison of Budgeting and Accounting Reforms in the Central Governments of France, Germany, the UK and the US, Financial Accountability \& Management, Vol. 29, No. 4, pp. 419-441.

Jorge, S. (2015). Public Sector Accounting and Auditing in Portugal, in I. Brusca, E. Caperchione, S. Cohen and F. Manes Rossi (eds), Public Sector Accounting and Auditing in Europe: The Challenge of Harmonization, pp. 156-172, Basingstoke: Palgrave Macmillan.

Khan, A. (2013). Accrual Budgeting: Opportunities and Challenges, in M. Cangiano, T. Curristine and M. Lazare (eds), Public Financial Management and Its Emerging Architecture, pp. 339-359, Washington, DC: International Monetary Fund.

Lüder, K. (1999). Developments in Public Sector Accounting, Speyer: Speyerer Arbeitshefte 125.

Lüder, K. (2002). Research in Comparative Governmental Accounting over the Last Decade: Achievements and Problems, in V. Montesinos and J.M. Vela (eds), Innovations in Governmental Accounting, pp. 1-21, Dordrecht: Kluwer. 
Why Cash-Based Budgeting Still Prevails in an Era of Accrual Reporting in the Public Sector

Manes Rossi, F. (2015). Public Sector Accounting and Auditing in Italy, in I. Brusca, E. Caperchione, S. Cohen and F. Manes Rossi (eds), Public Sector Accounting and Auditing in Europe: The Challenge of Harmonization, pp. 125-141, Basingstoke: Palgrave Macmillan.

Marti, C. (2013). Performance Budgeting and Accrual Budgeting: A Study of the United Kingdom, Australia, and New Zealand, Public Performance \& Management Review, Vol. 37, No. 1, pp. 33-58.

Mauro, S.G., Cinquini, L. and Grossi, G. (2016). Insights into Performance-Based Budgeting in the Public Sector: A Literature Review and Research Agenda, Public Management Review, forthcoming issue, doi.org/10.1080/14719037.2016.1243810.

Monsen, N. and Näsi, S. (1998). The Contingency Model of Governmental Accounting Innovations: A Discussion, European Accounting Review, Vol. 7, No. 2, pp. 275-288.

Monteiro, B.R.P. and Gomes, R.C. (2013). International Experiences with Accrual Budgeting in the Public Sector, Revista Contabilidade \& Finanças, Vol. 24, No. 62, pp. 103-112.

Moretti, D. (2016). Accrual Practices and Reform Experiences in OECD Countries: Results of the 2016 OECD Accruals Survey, OECD Journal on Budgeting, Vol. 16, No. 1, pp. 9-22.

PricewaterhouseCoopers (2015). Global Survey on Accounting and Reporting by Central Governments, second edition, July.

Rauskala, I. and Saliterer, I. (2015). Public Sector Accounting and Auditing in Austria, in I. Brusca, E. Caperchione, S. Cohen and F. Manes Rossi (eds), Public Sector Accounting and Auditing in Europe: The Challenge of Harmonization, pp. 12-26, Basingstoke: Palgrave Macmillan.

Robinson, M. (2009). Accrual Budgeting and Fiscal Policy, OECD Journal on Budgeting, Vol. 9, No. 1, pp. 1-29.

Robinson, M. (2016). Budget Reform Before and After the Global Financial Crisis, OECD Journal on Budgeting, Vol. 16, No. 1, pp. 29-63.

Schick, A. (2007). Performance Budgeting and Accrual Budgeting: Decision Rules or Analytic Tools?, OECD Journal on Budgeting, Vol. 7, No. 2, pp. 109-138.

Warren, K. (2015). Time to Look Again at Accrual Budgeting, OECD Journal on Budgeting, Vol. 14, No. 3, pp. 113-129.

Wildavsky, A. (1984). The Politics of the Budgetary Process, fourth edition, Boston, MA: Little, Brown and Company.

Wüstemann, J., Wüstemann S. and Conrath-Hargreaves, A. (2016). Harmonisierung der Öffentlichen Rechnungslegung in der Europäischen Union, Baden-Baden: Nomos. 